\title{
Effect of histone deacetylase and DNA methyltransferase inhibitors on the expression of the androgen receptor gene in androgen-independent prostate cancer cell lines
}

\author{
BARBORA FIALOVA $^{1}$, KATERINA SMESNY TRTKOVA ${ }^{1,2}$, \\ LENKA PASKOVA $^{1}$, KATERINA LANGOVA ${ }^{3}$ and ZDENEK KOLAR ${ }^{1}$
}

\begin{abstract}
${ }^{1}$ Laboratory of Molecular Pathology, Department of Clinical and Molecular Pathology, Faculty of Medicine and Dentistry, Palacky University Olomouc, 77515 Olomouc; ${ }^{2}$ Institute of Molecular and Translational Medicine, Palacky University and University Hospital, 77520 Olomouc; ${ }^{3}$ Department of Medical Biophysics, Faculty of Medicine and Dentistry, Palacky University Olomouc, 77515 Olomouc, Czech Republic
\end{abstract}

Received November 8, 2012; Accepted January 22, 2013

DOI: $10.3892 / o r .2013 .2344$

\begin{abstract}
Androgen receptor (AR) expression in prostate cancer $(\mathrm{CaP})$ cells varies due to the multiple changes including epigenetic modifications such as DNA methylation and histone deacetylation. DNA methyltransferase and histone deacetylase inhibitors are promising for the treatment of $\mathrm{CaP}$. The aim of our study was to analyze the 5-aza-2'-deoxycytidine (Aza-dC) and sodium butyrate $(\mathrm{NaB})$ effects on $\mathrm{CaP}$ cells with modified AR gene expression. The androgen-independent human prostate cancer cell lines PC3 (lacking a functional AR) and DU145 (strongly limited expression due to methylations in the AR gene) were used. PCR of bisulfite-modified DNA and RT-PCR with bisulfite-sequencing were used for AR gene analysis of DU145 and PC3 cells following their treatment with Aza-dC and/or $\mathrm{NaB}$. Re-acetylated histones around the AR gene were detected by conventional PCR of immunoprecipitated DNA obtained from treated cells. In both cell lines without the AR expression, the combined treatment was followed with significant decrease
\end{abstract}

Correspondence to: Dr Barbora Fialova, Laboratory of Molecular Pathology, Department of Clinical and Molecular Pathology, Faculty of Medicine and Dentistry, Palacky University Olomouc, Hnevotinska 3, 77515 Olomouc, Czech Republic

E-mail:babfia@gmail.com

Abbreviations: Aza-dC, 5-aza-2'-deoxycytidine; ADT, androgen deprivation therapy; $\mathrm{AR}$, androgen receptor; $\mathrm{BPH}$, benign prostate hyperplasia; $\mathrm{CaP}$, prostate cancer; CRPC, castration-resistant prostate cancer; DMSO, dimethylsulfoxide; DNMT, DNA methyltransferase; DNMTi, inhibitor of DNA methyltransferase; FBS, fetal bovine serum; HDACi, histone deacetylase inhibitor; HDACs, histone deacetylases; MTT, 3-(4,5-dimethylthiazol-2-yl)-2,5-diphenyltetrazolium bromide; $\mathrm{NaB}$, sodium butyrate; PSA, prostate specific antigen; TBP, TATAbinding protein; TMA, tissue microarray

Key words: androgen receptor, DNA methylation, histone acetylation, prostate cancer, epigenetics of cell viability. The co-treatment of DU145 cells caused sitespecific demethylation in the AR promoter region followed by gene re-expression and increased acetylation in histones $\mathrm{H} 3$ and $\mathrm{H} 4$. The co-treatment with Aza- $\mathrm{dC}$ and $\mathrm{NaB}$ was the most effective in demethylation and re-expression of the AR gene. In the AR gene promoter, the location and density of demethylated CpGs indicated the existence of distinct promoter hot spot that could be a target of AR gene inactivation therapy of $\mathrm{CaP}$ patients during androgen deprivation.

\section{Introduction}

The specific causes of prostate cancer $(\mathrm{CaP})$ remain unclear; however, it is known that androgens stimulate the growth of prostate cells through the androgen receptor (AR). In the treatment of $\mathrm{CaP}$, androgen deprivation is one of the most effective therapeutic approaches. However, androgen deprivation therapy (ADT) results in $\mathrm{CaP}$ progression. Once androgen stimulation has been eliminated, either surgically or pharmacologically, the AR continues to be active through a number of different mechanisms, including increased growth factor receptor signaling (1), insulin-like growth factor-1 (2) and interleukin-6 (3) as the main drivers. Resurgent AR can promote castration-resistant $\mathrm{CaP}$ (CRPC) formation and it has been shown to be both causative and sufficient to the lethal form of the disease (4). Mohler et al $(4,5)$ described that the intratumoral testosterone levels in patients with CRPC were similar to untreated benign prostatic disease. Furthermore, the CRPC tissue has levels of dihydrotestosterone which appear capable of activating the AR since prostate specific antigen (PSA) is expressed at similar tissue levels in castration-resistant and androgen-stimulated $\mathrm{CaP}$. They suggest a compelling paradigm shift; $\mathrm{CaP}$ that recurs during $\mathrm{ADT}$ is not androgen-independent. However it is possible but not confirmed, that cells primarily resistant to ADT are those with stem-cell properties that never required androgens for survival and growth (6). Overall, the results suggest that prostate tumors rarely encounter a completely androgen-depleted environment (7). An early hypothesis, in which most CRPC 
bypassed AR-regulated signaling pathways, was supported by the fact that commonly studied androgen-independent $\mathrm{CaP}$ cell lines, such as DU145 and PC3, did not express AR. To date, little information is available about the DNA methylation pattern on the AR after the short- and long-term androgen exposure or removal (8).

Among the different types of epigenetic changes, the most studied are DNA methylation and histone modifications (8-10). DNA hypermethylation in the promoter region is an important epigenetic mechanism for the downregulation of gene expression. However, the epigenetic mechanisms that lead these changes to cancer have yet to be fully clarified.

Epigenetics is defined as the heritable change in gene expression without change in DNA sequence (9). A number of these epigenetic modifications is reversible and, therefore, offers an opportunity for epigenetically targeted antitumor therapy. Generally, acetylation of histones can be reversed by histone deacetylases (HDACs) that remove acetyl groups and finally cause transcriptional inactivation. Histone deacetylase inhibitors (HDACi) cause a return of acetylated histones with incidences in activation of gene expression. In our study, the sodium butyrate $(\mathrm{NaB})$, a naturally occurring HDACi with an inhibitory effect on endometrial and ovarian cancer cells (11) and with an ability to inhibit growth of colon and prostate cancer was used. Furthermore, agent 5'-aza-2-deoxycytidine (Aza-dC) is a well-known inhibitor of DNA methyltransferases (DNMTi). The Aza-dC acts through an irreversible and covalent binding to DNA methyltransferases followed by hypomethylation of replicating DNA (12).

Several studies have focused on an effect of DNMTi in CRPC to determine whether re-expressed AR gene can lead to the decrease of aggressive $\mathrm{CaP}(13,14)$. These in vivo studies found that Aza-dC treatment delayed $\mathrm{CaP}$ progression to androgen-independent disease and prolonged survival in the TRAMP mouse model of CaP. Experiments in re-expression of AR gene using DNMTi are ongoing as epigenetically targeted antitumor therapies utilizing re-expressed AR gene in combination with other therapies could be a new promising method for patients with CRPC (15).

The aim of our study was to investigate combined effect of DNA demethylation and histone re-acetylation on re-expressed AR on AR-negative CaP cell lines PC3 and DU145 (both representing the CRPC model) and to elucidate the potential effect of the re-expressed AR in these cancer cells. The Aza-dC and $\mathrm{NaB}$ as a combination of DNMTi and HDACi, respectively, may be able to suppress the viability of $\mathrm{CaP}$ cells and may contribute to slowing down the progression.

\section{Materials and methods}

Cell culture and cell conditions. In addition to the androgenindependent human CaP cell lines PC3 and DU145, androgen-independent $\mathrm{C} 4-2$ cell line was used for comparison due to its AR gene expression (16). The PC3 and DU145 cell lines were purchased from the ATCC (Rockville, MD, USA), the C4-2 cell line was purchased from UroCor Labs (Oklahoma City, OK, USA). DU145 and PC3 cells were maintained in DMEM (Gibco) supplemented with $10 \%$ fetal bovine serum (FBS), $0.01 \%$ antibiotics, $2 \mathrm{mM}$ L-glutamine. C4-2 cells were maintained in RPMI-1640 media (Sigma,
St. Louis, MO, USA) supplemented with a final $10 \%$ concentration of FBS, $0.01 \%$ antibiotics, $2 \mathrm{mM}$ L-glutamine and $1 \mathrm{mM}$ sodium pyruvate. All cells were maintained at $37^{\circ} \mathrm{C}$ in a $5 \% \mathrm{CO}_{2}$ atmosphere.

Treatment with DNMTi and HDACi. The PC3 and DU145 cell lines were treated with $\mathrm{NaB}$ (Sigma-Aldrich, St. Louis, MO, USA), Aza-dC (Sigma-Aldrich) and combinations of Aza-dC and $\mathrm{NaB}$ for $48 \mathrm{~h}$ and 6 days when medium and agents were exchanged after $48 \mathrm{~h}$.

Cell viability assay. Cell viability was assessed by the 3-(4,5-dimethylthiazol-2-yl)-2,5-diphenyltetrazolium bromide (MTT) assay to determine the $50 \%$ inhibition of viability $\left(\mathrm{IC}_{50}\right)$ concentrations of the studied agents as previously described (17). Both cell lines (35-40\% confluent) were treated with $\mathrm{NaB}$ or Aza-dC or their combinations. The concentration leading to $\mathrm{IC}_{50}$ was determined by measuring absorbance at $570 \mathrm{~nm}$, using a Labsystems Multiskan RC ELISA reader. The viability of treated cells was expressed as a percentage relative to the viability of control vehicle-treated cells (18). Cell viability assay was conducted in triplicate wells and represents at least three independent experiment.

Sodium-bisulfite modification and DNA methylation analysis. Genomic DNA was isolated by the Wizard ${ }^{\circledR}$ Genomic DNA Purification kit (Promega, Madison, WI, USA) and sodiumbisulfite modification was made with the EpiTect ${ }^{\circledR}$ Bisulfite kit (Qiagen, Hilden, Germany) according to the manufacturer's protocol. PCR amplification was performed with the following primers: M2/F, 5'-TGG TTT AGG AAA TTA GGA GTT ATT TAG G-3' and M2/R, 5'-TCC CTT CGA CTC CTA TAC AAC ACT A-3' by initial denaturation at $94^{\circ} \mathrm{C}$ for $4 \mathrm{~min}$, followed by 35 cycles of denaturation at $94^{\circ} \mathrm{C}$ for $1 \mathrm{~min}$, annealing at $52^{\circ} \mathrm{C}$ for $50 \mathrm{sec}$, elongation at $72^{\circ} \mathrm{C}$ for $1 \mathrm{~min}$, and the final extension at $72^{\circ} \mathrm{C}$ for an additional $15 \mathrm{~min}$ after the last cycle. The PCR with M4 primers/F, 5'-AGT TTG TAG AGA GGT AAT TTT TTT TGG T-3' and M4/R, 5'-CCT AAC TAC CTT TTC ATC TTT TAA TCT-3' was performed with annealing at $50^{\circ} \mathrm{C}$ under the same conditions as previously described. M2 primers were designed for amplification of $383 \mathrm{bp}$ in the promoter region and M4 primers amplified 235 bp region of exon 1 of AR gene (Fig. 1, numbering according to the CAG-transcription initiation site II) (19). Both were proposed to amplify only unmethylated DNA after sodium-bisulfite modification. The bisulfite-modified DNA was used in 25- $\mu 1$ PCR reaction mixture with DyNAzyme ${ }^{\mathrm{TM}}$ EXT DNA Polymerase (Finnzymes, Espoo, Finland). The PCR products were electrophoresed in $1.0 \%$ TAE agarose gels and visualized by ethidium bromide staining.

Bisulfite-sequencing. The DU145 and PC3 samples after the bisulfite modification and methylation analysis amplified with M2 and M4 primers, respectively, were purified with QIAEX ${ }^{\circledR}$ II Gel Extraction kit (Qiagen, Hilden, Germany) or QIAquick ${ }^{\circledR}$ PCR Purification kit (Qiagen). GenomeLab ${ }^{\text {TM }}$ DTCS Quick Start kit (Beckman Coulter, Brea, CA, USA) and Beckman Coulter sequence analyzer were used for sequence analysis. Bisulfite-sequenced samples were aligned with wild-type AR sequence (NC_000023.10). 


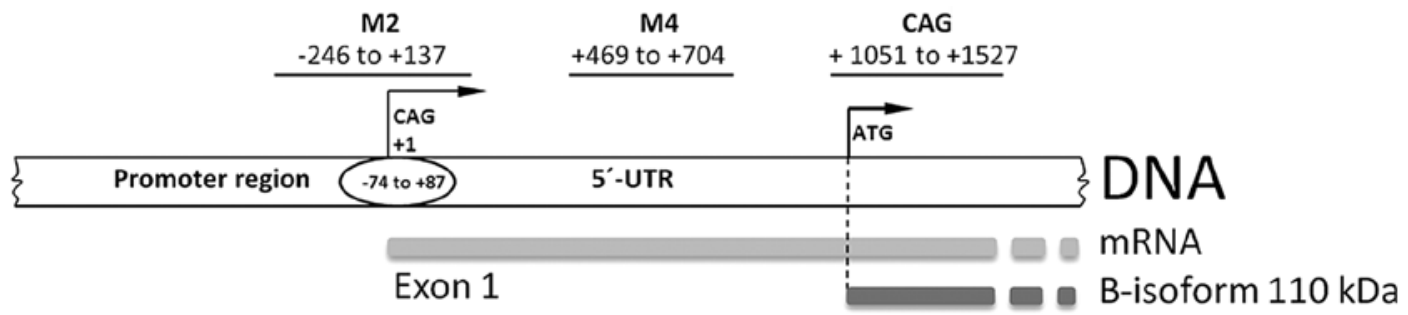

Figure 1. AR gene promoter region including promoter core (in oval) and 5'-UTR region. Simplified illustration depicting positions of PCR primers used in this study. PCR primers used in ChIP analysis are not shown.

cDNA analysis. Total RNA was isolated with the High Pure RNA Isolation kit and converted to cDNA using the Transcriptor First Strand cDNA Synthesis kit (Roche, Diagnostics, Basel, Switzerland) according to the manufacturer's instructions. The CAG primers were proposed for amplification of the 476-bp polymorphic $\mathrm{CAG}$ region of the AR gene. The following primers were applied to detect AR expression: $\mathrm{CAG} / \mathrm{F}, 5$ '-CCT GTT GAA CTC TTC TGA G-3' and CAG/R, 5'-TCT GGG ACG CAA CCT CTC-3'. PCR amplification was initially denatured at $94^{\circ} \mathrm{C}$ for $4 \mathrm{~min}$, followed by 40 cycles of denaturation for $40 \mathrm{sec}$, annealing at $58^{\circ} \mathrm{C}$ for $40 \mathrm{sec}$, elongation at $72^{\circ} \mathrm{C}$ for $1 \mathrm{~min}$ and the final extension at $72^{\circ} \mathrm{C}$ for an additional $10 \mathrm{~min}$ after the last cycle. The primers were designed for amplification of wild-type human DNA without sodium-bisulfite modification. For internal control, 89-bp PCR product of the TATA-binding protein (TBP) gene was amplified. DNA isolated from a healthy man served as a positive control for expression of the AR gene. Results were confirmed by a further independent PCR amplification.

Chromatin immunoprecipitation (ChIP). ChIP was performed as described by Trtkova et al (20) with slight modifications. Briefly, cells in 100-mm dishes were cross-linked with $1 \mathrm{ml}$ of 11x formaldehyde stock solution (1\% final concentration of formaldehyde). Cross-linking was stopped by the addition of glycine and cells were washed with PBS. The cells were scraped and lysed in Chro-IP lysis buffer containing protease inhibitors (Complete Protease Inhibitor Cocktail, Roche Diagnostics). The lysates were reversed on a rotator for $10 \mathrm{~min}$ and after centrifugation at $600 \mathrm{~g}$ for $5 \mathrm{~min}$ at $4^{\circ} \mathrm{C}$ followed by washing. Following centrifugation $\left(600 \mathrm{~g}\right.$ for $5 \mathrm{~min}$ at $\left.4^{\circ} \mathrm{C}\right)$ pellets were resuspended in 1x RIPA buffer, sonicated and then centrifuged at $16.000 \mathrm{~g}$ for $10 \mathrm{~min}$ at $4^{\circ} \mathrm{C}$. Anti-acetylhistone $\mathrm{H} 3$, anti-acetyl-histone $\mathrm{H} 4$ and normal mouse IgG antibodies (Millipore, Upstate Biotechnology, Temecula, CA, USA) were added to aliquots of $600 \mu \mathrm{g}$ of chromatin protein lysates and incubated with rotation at $4^{\circ} \mathrm{C}$ overnight. Salmon sperm DNA/Protein G agarose (Upstate Biotechnology) was added to the samples and incubated with rotation at $4^{\circ} \mathrm{C}$ for $1 \mathrm{~h}$. The samples were centrifuged $\left(600 \mathrm{~g}\right.$ for $3 \mathrm{~min}$ at $\left.4^{\circ} \mathrm{C}\right)$ and the pellets were washed with 1x RIPA buffer containing $100 \mu \mathrm{g} / \mathrm{ml}$ salmon sperm DNA, then with Low salt and High salt immune complex wash buffer and finally again with 1x RIPA buffer containing $100 \mu \mathrm{g} / \mathrm{ml}$ salmon sperm DNA. Following centrifugation, $100 \mu \mathrm{l}$ of elution buffer was added and samples were placed at $65^{\circ} \mathrm{C}$ for $20 \mathrm{~min}$ with occasional gentle agitation. The agarose beads were removed by centrifugation when the supernatants were moved to new tubes. The cross-linking was reverted by heating at $65^{\circ} \mathrm{C}$ for $6 \mathrm{~h}$ and then proteinase $\mathrm{K}(100 \mu \mathrm{g} / \mathrm{ml})$ was added to each tube and incubated at $55^{\circ} \mathrm{C}$ overnight with gentle agitation. DNA was purified with QIAquick ${ }^{\circledR}$ PCR Purification kit (Qiagen) according to the manufacturer's instructions. For input we added $50 \mu \mathrm{g}$ of each chromatin lysate and $0.5 \mu \mathrm{l}$ of proteinase $\mathrm{K}(100 \mu \mathrm{g} / \mathrm{ml})$ to each tube and incubated at $55^{\circ} \mathrm{C}$ for $3 \mathrm{~h}$ with gentle agitation followed by DNA purification. PCR amplification was performed with the following primers: forward, 5'-GTT TAG GAA ACC AGG AGC TAT TCA-3' and reverse, 5'-GTA CAG CAC TGG AGC GGC TA-3' identical to PCR conditions for $\mathrm{M} 2$ primers with modification in annealing temperature $\left(58^{\circ} \mathrm{C}\right)$ and in elongation time $(80 \mathrm{sec})$. These primers were designed for amplification of $369 \mathrm{bp}$ in the promoter region of wildtype AR gene and partially overlap with the sequences of M2 primers.

Statistical analysis. Multifactoral analysis of variance (ANOVA) with a post-hoc two-sided Dunnett's t-test was used to compare cell viability between treatments and the vehicle-control when a single concentration was assessed. Multifactoral ANOVA with a post-hoc Bonferroni multiple comparison test was used to compare cell viability between treatments and the vehicle control when time points and individual cell line were assessed. Analyses were performed with the SPSS software version 15 (SPSS, Inc., Chicago, IL, USA) and statistical significance of differences was set at $\mathrm{P}<0.05$ (two-sided).

\section{Results}

Cell viability assay in DU145 and PC3 cells. The DU145 and PC3 cell viabilities treated with $\mathrm{NaB}$ and Aza-dC (as a single agent or in combinations) were assessed by MTT assay. In comparison to the control DMSO, the $\mathrm{NaB}$ treatment for $48 \mathrm{~h}$ induced a decrease of PC3 cell viability by concentrations from $0.75 \mathrm{mM}$ up to $5 \mathrm{mM}(\mathrm{P}=0.06$ for $0.75 \mathrm{mM}, \mathrm{P}=0.001$ for $1 \mathrm{mM}$ and $\mathrm{P}<0.0001$ for other concentrations) (Fig. 2A). In the case of DU145 cells, effective NaB concentration to suppress cell viability was from $\geq 0.5 \mathrm{mM}(\mathrm{P}=0.07$ for $0.5 \mathrm{mM}$, $\mathrm{P}=0.004$ for $0.75 \mathrm{mM}$ and $\mathrm{P}<0.0001$ for higher concentrations) (Fig. 2A). Differences in viability between both cell lines were significant at the following $\mathrm{NaB}$ concentrations: $0.025 \mathrm{mM}$ $(\mathrm{P}=0.004), 2.5 \mathrm{mM}, 4 \mathrm{mM}(\mathrm{P}<0.0001)$ and $5 \mathrm{mM}(\mathrm{P}=0.0003)$ in favor of the PC3 cells. Thus, the NaB treatment appears to be more toxic for DU145 cells compared to PC3 cell survival. Use of Aza-dC and its co-treatment with $\mathrm{NaB}$ for $48 \mathrm{~h}$ resulted in a decrease of cell viability in PC3 cells $(\mathrm{P}<0.0001$ 

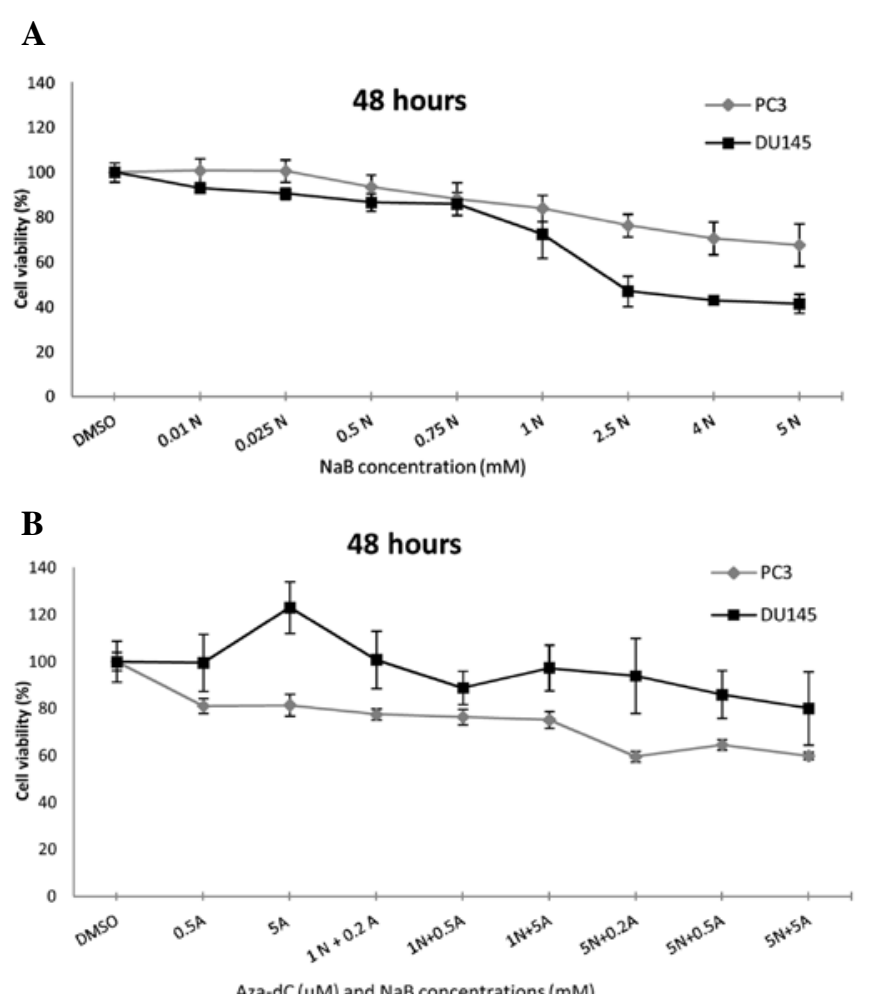

C

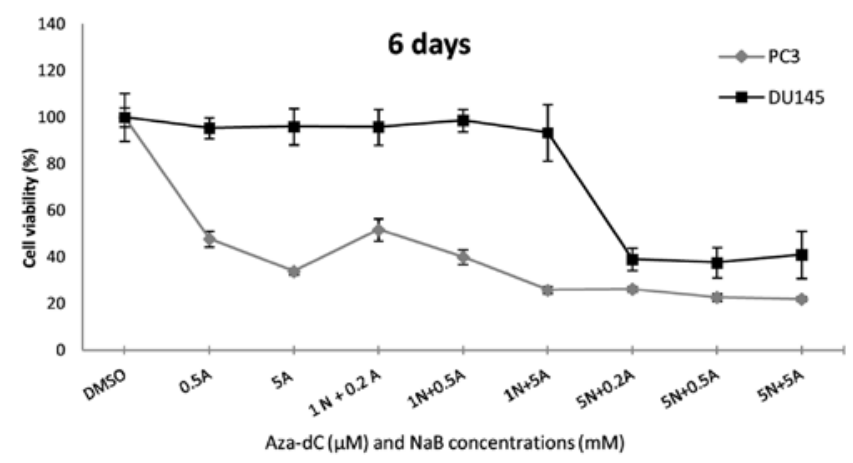

Figure 2. (A and B) DU145 and PC3 cell viabilities after 48-h treatment and (C) 6-day treatment with $\mathrm{NaB}$ alone or in combinations with Aza-dC. Both prostate cancer cells $\left(4 \times 10^{3}\right.$ cells/well in 96 -well plates) were treated with increasing doses of Aza-dC, $\mathrm{NaB}$ or their combination, and medium with inhibitors was changed after $48 \mathrm{~h}$ for 6-day treatments. Data at each treatment point represent the means $\pm \mathrm{SE}$ of at least triplicate wells. Multifactoral ANOVA analyzed the effect of the following factors: type and concentration of used inhibitors, type of cell line and time of treatment ( $48 \mathrm{~h}$ vs. 6 days) on cell viability. This method proved statistically significant effects of all factors and their mutual interactions on the cell viability. $0.5 \mathrm{~A}, 0.5 \mu \mathrm{M}$ Aza-dC; $5 \mathrm{~A}$, $5 \mu \mathrm{M}$ Aza-dC; $1 \mathrm{~N}+0.2 \mathrm{~A}, 1 \mathrm{mM} \mathrm{NaB}$ with $0.2 \mu \mathrm{M}$ Aza-dC; $1 \mathrm{~N}+0.5 \mathrm{~A}, 1 \mathrm{mM}$ $\mathrm{NaB}$ with $0.5 \mu \mathrm{M}$ Aza-dC; $1 \mathrm{~N}+5 \mathrm{~A}, 1 \mathrm{mM} \mathrm{NaB}$ with $5 \mu \mathrm{M}$ Aza-dC; $5 \mathrm{~N}+0.2 \mathrm{~A}$, $5 \mathrm{mM} \mathrm{NaB}$ with $0.2 \mu \mathrm{M}$ Aza-dC; $5 \mathrm{~N}+0.5 \mathrm{~A}, 5 \mathrm{mM} \mathrm{NaB}$ with $0.5 \mu \mathrm{M}$ Aza-dC $5 \mathrm{~N}+5 \mathrm{~A}, 5 \mathrm{mM} \mathrm{NaB}$ with $5 \mu \mathrm{M}$ Aza-dC.

for all concentrations) and in DU145 cells only by $5 \mu \mathrm{M}$ Aza-dC+1 mM NaB (P=0.041) (Fig. 2B) compared to DMSO treatments. Moreover, in DU145 cells we detected increased cell viability after $5 \mu \mathrm{M}$ Aza-dC treatment $(\mathrm{P}=0.008)$. Under all concentrations used in this treatment, the cell viability of both lines exhibited significantly different cytotoxicity ( $\mathrm{P}=0.009$ and less). Fig. 2C with 6-day exposure shows a strong decrease of viability of $\mathrm{PC} 3$ cells compared to DMSO $(\mathrm{P}<0.0001$ for all doses), while in DU145 cells, a decrease of viability after treatments with all concentrations of Aza-dC
A

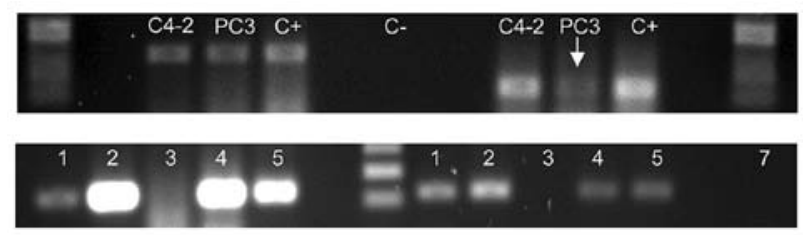

C

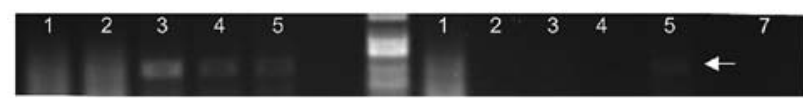

D

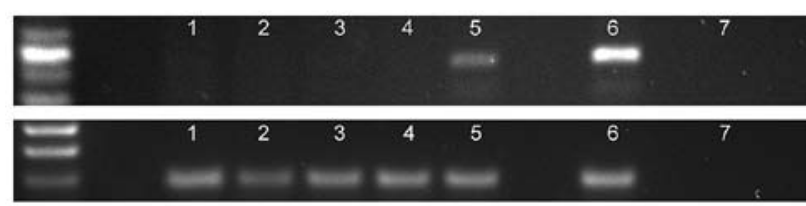

Figure 3. PCR methylation analysis. (A) Methylation analysis of promoter (M2 primers, $383 \mathrm{bp}$, left) and 5'-UTR (M4 primers, $235 \mathrm{bp}$, right, with arrow) in exon 1 of the AR gene in PC3 cells. C+ PCR positive control; C- PCR negative control. Untreated DNA from C4-2 cells served as positive control of unmethylated AR gene. (B) Demethylation effect after the 48-h (left) and 6-day treatments (right) with Aza-dC alone or in combination with $\mathrm{NaB}$ in PC 3 cells (M4 primers). Numbers represent individual treatments: 1 - DMSO, 2 - $0.5 \mu \mathrm{M}$ Aza-dC, 3 - $5 \mu \mathrm{M}$ Aza-dC, 4- $0.5 \mu \mathrm{M}$ Aza-dC with $1 \mathrm{mM} \mathrm{NaB}$, 5 - $5 \mu \mathrm{M}$ Aza-dC with $5 \mathrm{mM} \mathrm{NaB}, 7$ - PCR negative control. (C) Demethylation effect after the 48-h (left) and 6 day treatments (right) with Aza-dC alone or in combination with $\mathrm{NaB}$ in DU145 cells (M2 primers). Treatments numbers are identical with previous, arrow indicates PCR product. (D) PCR amplification of cDNA (CAG primers, $476 \mathrm{bp}$, upper panel) of the AR gene from DU145 cells (48-h treatment). Control PCR amplification of TBP housekeeping gene (98-bp product, lower panel). Treatments numbers are identical with previous, 6- PCR positive control, 7 - PCR negative control.

with $5 \mathrm{mM} \mathrm{NaB}$ was apparent. Furthermore, despite the cell viability decrease after the final three co-treatments in DU145 cells, the effect of the agent used is significantly more favorable for DU145 cell viability compared to the PC3 line at all concentrations $(\mathrm{P}<0.001$ for $0.2 \mu \mathrm{M}$ Aza- $\mathrm{dC}+1 \mathrm{mM} \mathrm{NaB}$ and $\mathrm{P}<0.0001$ for the others).

DNA methylation status and demethylation effect of Aza-dC and $N a B$ on the AR gene promoter and 5'-UTR region. The M2 and M4 primers amplified unmethylated CpGs of bisulfite-modified DNA. Using M2 primers, the 383-bp PCR product obtained from PC3 cells indicated unmethylated promoter (Fig. 3A, left part) whereas in 5'-UTR we suggest methylation changes (Fig. 3A, right part). Methylation analysis of DU145 cells resulted in 235-bp PCR product amplification of the 5'-UTR and failed amplification in the promoter region (data not shown).

The Aza-dC $(0.5$ and $5 \mu \mathrm{M})$ and combinations $0.5 \mu \mathrm{M}$ Aza-dC with $\mathrm{NaB}$ ( 1 and $5 \mathrm{mM}$ ) were used for determination of DNA demethylation effect in AR-negative cell lines. Treatment of PC 3 cells with Aza-dC and used combinations with $\mathrm{NaB}$ for $48 \mathrm{~h}$ (Fig. 3B, treatments marked by numbers 1-5, left part) and 6 days (right part) resulted in amplification of 235-bp PCR products. The 48-h treatment of DU145 cells with Aza-dC and its combinations with $\mathrm{NaB}$ is shown in Fig. 3C. Unmethylation specific M2 primers generated 383-bp PCR product in the promoter region of the AR gene (48-h treatment, left part) and only $0.5 \mu \mathrm{M}$ Aza-dC and $5 \mathrm{mM} \mathrm{NaB}$ co-treatment generated PCR products after a 6-day exposure (right part). 
A

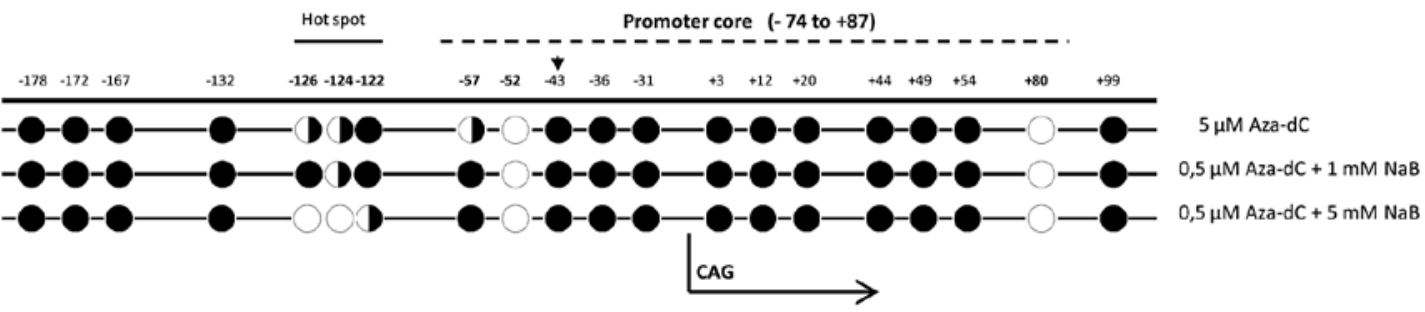

B $5 \mu \mathrm{M}$ Aza-dC

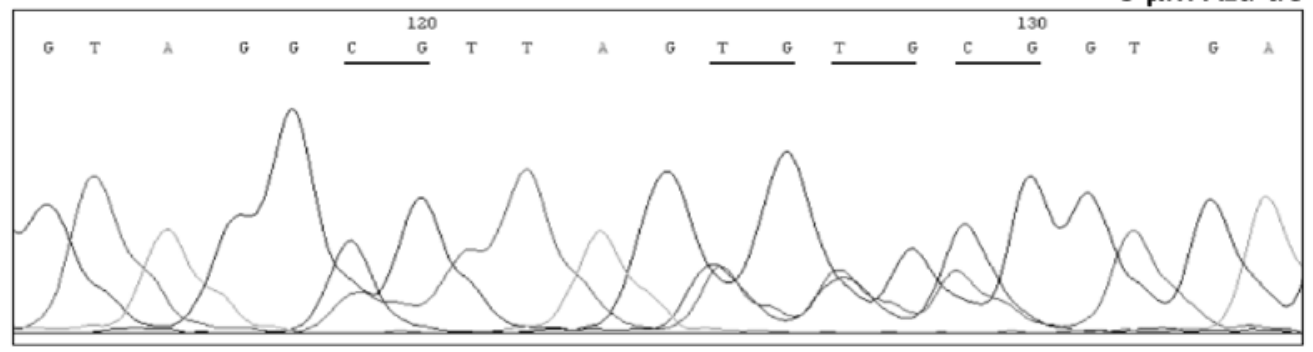

$0.5 \mu \mathrm{M}$ Aza-dC + $1 \mathrm{mM} \mathrm{NaB}$

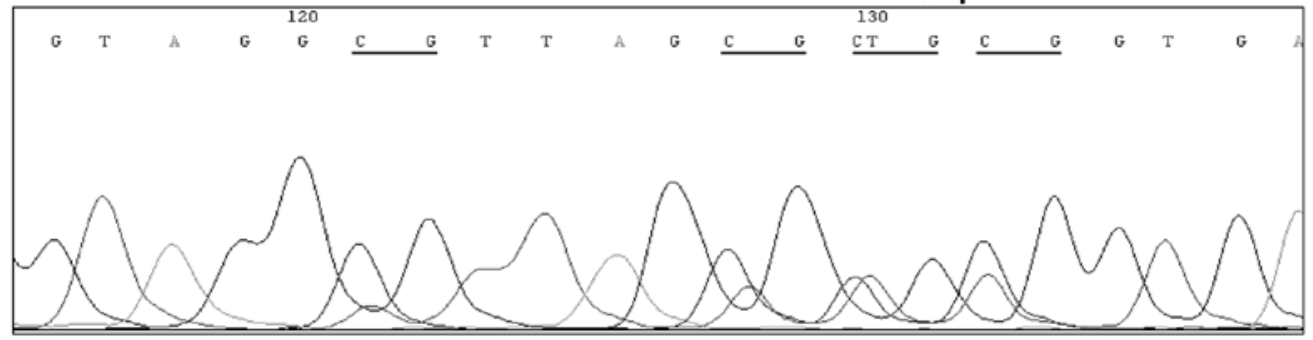

$0.5 \mu \mathrm{M}$ Aza-dC $+5 \mathrm{mM} \mathrm{NaB}$

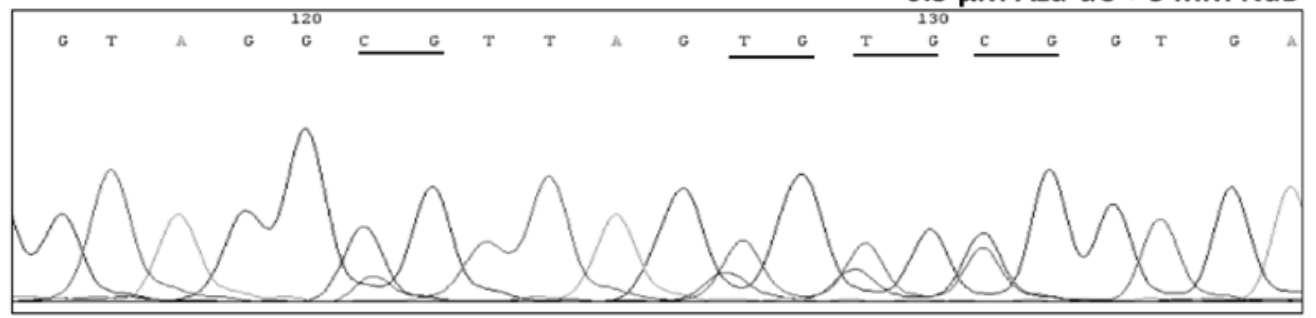

Figure 4. Methylation status of individual CpG sites in the AR promoter sequence of DU145 cells after 48-h treatment with Aza-dC or in combination with $\mathrm{NaB}$. (A) The core promoter (dashed line) and hot spot (full line) are also depicted. Spl binding site is depicted with the arrow. The methylation status at each $\mathrm{CpG}$ site from the sequencing profile was estimated by comparison of the relative peak height of the cytosine (C) vs. thymine (T), therefore, the methylation level of each CpG site was assessed as either $<50 \%, 50: 50 \%$ or $>50 \%$ of methylated DNA. (B) Alignment of treated DU145 cells with partially or completely demethylated CpGs in the promoter region of the AR gene, including - $132 \mathrm{CpG}$ site and hot spot in positions - $126,-124$ and -122 (underlined).

In DU145 cells, we analyzed whether the demethylation effect induced by the combination of $0.5 \mu \mathrm{M} \mathrm{Aza-dC}$ and $5 \mathrm{mM} \mathrm{NaB}$ could result in the re-expression of the AR gene. We performed cDNAs using reverse-transcription (RT) PCR after $48 \mathrm{~h}$ of treatment and, using CAG primers, we amplified the $\mathrm{CAG}$ region in exon 1 of the AR gene. In Fig. 3D (upper panel), only the combination of $0.5 \mu \mathrm{M} \mathrm{Aza-dC}$ and $5 \mathrm{mM}$ $\mathrm{NaB}$ was effective in restoring the AR gene expression. The unaffected TBP gene expression served as internal control (Fig. 3D, lower panel).

Bisulfite-sequencing of the AR gene promoter and 5'-UTR region in cells treated with $A z a-d C$ and $N a B$. Sequencing data from DU145 cells are shown in Fig. 4. The similar demethylation pattern $(-52$ and +80$)$ in sequences of all tested treatments was found in the AR gene promoter. Treatment with $5 \mu \mathrm{M}$ Aza-dC caused partial demethylation in $-126,-124$ and $-57 \mathrm{CpG}$ sites. Combination of $0.5 \mu \mathrm{M}$ Aza-dC and $1 \mathrm{mM} \mathrm{NaB}$ induced partial demethylation in -124 position and co-treatment with $0.5 \mu \mathrm{M}$ Aza-dC and $5 \mathrm{mM} \mathrm{NaB}$ resulted in complete demethylation of $\mathrm{CpGs}$ in positions -126,-124 and partial demethylation at the -122 site. Sequence analysis in PC-3 cells treated with Aza-dC alone and with Aza-dC and $\mathrm{NaB}$ combinations showed demethylation of all identified CpG sites in the 5'-UTR region (data not shown). Collectively, the most effective DNA demethylation effect was evident after co-treatment of the DU145 cells with $0.5 \mu \mathrm{M}$ Aza-dC and $5 \mathrm{mM} \mathrm{NaB}$.

Amplification of androgen receptor from chromatin immunoprecipitated DNA. ChIP analysis was performed with DU145 
DU145

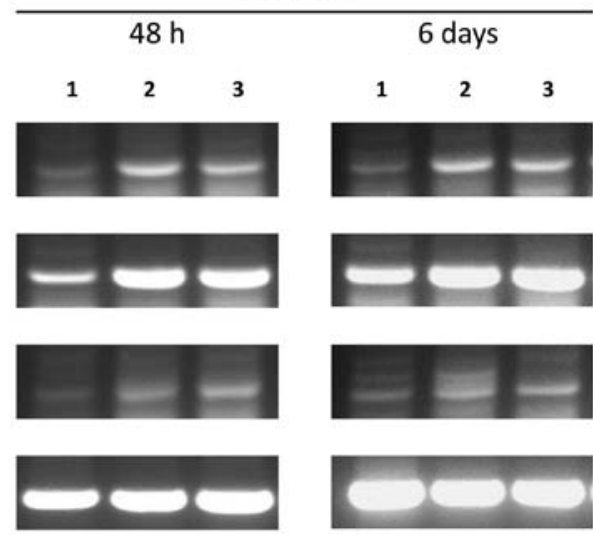

Figure 5. Conventional PCR with DNA after ChIP in DU145 cells. Untreated cells (DMSO; treatment 1), cells treated with $5 \mathrm{mM} \mathrm{NaB}$ (treatment 2) or $0.5 \mu \mathrm{M}$ Aza-dC with $5 \mathrm{mM} \mathrm{NaB}$ (treatment 3 ) for $48 \mathrm{~h}$ and 6 days were immunoprecipitated with acetyl-histone $\mathrm{H} 3$ and $\mathrm{H} 4$ antibodies and amplified with wild-type primers specific for AR gene promoter (369-bp DNA fragment).

cell line in order to determine and compare the status of acetylhistone $\mathrm{H} 3$ and acetyl-histone $\mathrm{H} 4$ adjacent to the AR gene. For comparison we worked with the highest concentration of $\mathrm{NaB}(5 \mathrm{mM})$ and with the combination of $0.5 \mu \mathrm{M}$ Aza-dC and $5 \mathrm{mM} \mathrm{NaB}$ that was effective in restoring the AR gene expression. After both treatments, we found increased acetylations in histones $\mathrm{H} 3$ and $\mathrm{H} 4$ in the $\mathrm{AR}$ gene promoter region compared to untreated control (Fig. 5).

\section{Discussion}

We studied epigenetic consequences of using the combination of DNA demethylation agent and histone deacetylase inhibitor in androgen-independent cells. In the both cell lines without the AR gene expression, the co-treatment with 5-aza-2'-deoxycytidine and sodium butyrate was more effective in demethylation of specific $\mathrm{CpG}$ sites in the androgen receptor (AR) gene promoter than Aza-dC treatment only (Fig. 4). We found that the AR gene re-expression was accompanied by increased acetylation in histones $\mathrm{H} 3$ and $\mathrm{H} 4$ (Fig. 5).

The $\mathrm{CpG}$ islands methylations in the promoter region affect gene transcription and is generally regarded as a common form of gene expression regulation. For this reason, gene promoter sites that are methylated and associated with a loss of gene transcription might be identified as the sequence important or critical for gene transcription. Evidence of the epigenetic regulation of the AR is finding that androgenindependent prostate cancer $(\mathrm{CaP})$ cell lines are associated with the AR gene hypermethylation and loss of the AR gene expression $(14,21)$. Jarrard et al (21) further demonstrated that treatment with the Aza-dC induced re-expression of the AR gene in several metastatic $\mathrm{CaP}$ cells followed by induction of the prostate specific antigen (PSA) gene expression, while DU145 cells remained intact to treatment even in long-term culture. Although normal prostate epithelial cells showed no DNA methylation, the AR gene hypermethylation has been detected in $20 \%$ of 10 primary and $28 \%$ of 14 hormone-refractory $\mathrm{CaP}$ samples (22). In our study, we found that $\mathrm{CpG}$ sites from -126 to -122 nucleotide positions, previously known as hot spot (23), were partially or completely demethylated in DU145 cells. Demethylated CpG sites located upstream of the core AR gene promoter (-126 to -122) could represent hot spot important for AR gene transcription. These CpGs might be targets of AR gene-inactivation therapy and may therefore be more effective compared to the current use of androgen deprivation. In addition, complete demethylation in two CpG sites $(-52$ and +80$)$ (Fig. 4) adjacent to the promoter core of the AR gene (-74 to +87 ) was detected. However, the position -43 in promoter core, representing Sp1 binding site for Sp1 transcription factor (24), stayed methylated as was confirmed by sequencing (Fig. 4). Similarly, the study conducted by Mishra et al (25) suggested that most $\mathrm{CpG}$ sites remain methylated, although demethylations following Aza-dC were significant.

It is known that nucleoside analogs, Aza-dC and/or 5-azacytidine (5-Aza) are incorporated into DNA during replication and inhibit methyltransferase activity. In addition, methylation of cytosines in and around genes can result in the gene silencing. DNA methylation possibly alters chromosome structure and defines regions important for transcriptional regulation (26). Thus, DNA methylation and histone hypoacetylation appear to be distinct but connected silencing mechanisms (26-28). Moreover, using combination of the DNA methylation and HDACi might overcome a disadvantage of the $\mathrm{NaB}$ instability (29) and obtains a benefit from their synergistic effect. There is also a molecular rationale for the combination of HDACi with demethylating agents since hypermethylation can lead to compact nucleosomes resistant to re-acetylation (30). The precise mode of action of HDACi in $\mathrm{CaP}$ cells is not completely understood. The $\mathrm{NaB}$ exerts an extensive inhibitory effect on HDAC activities but it is a relatively weak HDACi for millimolar concentration requirements and low specificity in inducing gene expression $(30,31)$. In our study, the Aza-dC and $\mathrm{NaB}$ single and particularly combined treatment induced significant cytotoxic effects in both cell lines (Fig. 2, compared to normal prostate cells RWPE1, our unpublished results). In other studies $(32,33)$ the $\mathrm{NaB}$ administration to $\mathrm{CaP}$ cells increased the percentage of cells in G1 phase and induced apoptosis. We observed a dose-dependent decrease of cell viability in both lines that could be a consequence of demethylation and re-expression of pro-apoptotic and anti-proliferative genes (15,32-34).

If classifications of alterations in AR signaling include AR gene amplifications and mutations, changes in the level of ligand, changes in coregulatory molecules including coactivators and corepressors, increased levels of protein due to gene amplification or altered mRNA expression, upregulation of pathways that activate AR in the absence of androgens $(5,9)$, there are several possibilities to explain why the PC 3 cells do not express functional AR despite ambiguously detected methylations in AR gene $(16,35)$. As described by Mizokami and Chang (36), the entire sequence from +21 to +149 nucleotide positions, including a stem-loop secondary structure at +109 to +129 of AR 5'-UTR (also known as hairpin or hairpin loop) may be needed for an induction of translation. In PC3 cells, we found completely unmethylated or demethylated sequence part of 5'-UTR (Fig. 3B and D).

Finally, our results suggest the role of induced histone re-acetylation on DNA demethylation with possible respon- 
sibility for epigenetic inactivation of AR gene expression that warrants further research. Our findings may help to elucidate the effects of HDAC and DNMT inhibitors on the androgenindependent $\mathrm{CaP}$ cells representing the CRPC model.

\section{Acknowledgements}

The authors thank Jana Holinková, Eva Pimrová and Ondřej Bláha for their technical assistance. Professor Zoran Culig from the University of Innsbruck is acknowledged for editing and modifying the manuscript. We also thank Sylwia Jančik for the assistance with sequencing. This study was supported by grants NS10262-3/2009 from the Czech Ministry of Health, Grant Agency of the Czech Republic 303/09/H048 and LF_2012_019.

\section{References}

1. Knudsen K and Kelly WK: Outsmarting androgen receptor: creative approaches for targeting aberrant androgen signaling in advanced prostate cancer. Expert Rev Endocrinol Metab 6: 483-493, 2011

2. Gao F, Yang M, Luo L and Wu XH: Local insulin-like growth factor-I of ventral prostate was upregulated during long-term castration and may function through the autocrine system. Prostate Cancer Prostatic Dis 14: 136-142, 2011.

3. Culig Z and Puhr M: Interleukin-6: a multifunctional targetable cytokine in human prostate cancer. Mol Cell Endocrinol 360 $52-58,2012$.

4. Mohler JL, Gregory CW, Ford OH III, Kim D, Weaver CM, Petrusz P, Wilson EM and French FS: The androgen axis in recurrent prostate cancer. Clin Cancer Res 10: 440-448, 2004.

5. Mohler JL: Castration-recurrent prostate cancer is not androgenindependent. Adv Exp Med Biol 617: 223-234, 2008.

6. Scher HI and Sawyers CL: Biology of progressive, castrationresistant prostate cancer: directed therapies targeting the androgen-receptor signaling axis. J Clin Oncol 23: 8253-8261, 2005.

7. Imamura T: Epigenetic setting for long-term expression of estrogen receptor $\alpha$ and androgen receptor in cells. Horm Behav 59: 345-352, 2011.

8. Esteller M: Epigenetics in cancer. N Engl J Med 358: 1148-1159, 2008.

9. Gao L and Alumkal J: Epigenetic regulation of androgen receptor signaling in prostate cancer. Epigenetics 5: 100-104, 2010.

10. Martinez-Arguelles DB and Papadopoulos V: Epigenetic regulation of the expression of genes involved in steroid hormone biosynthesis and action. Steroids 75: 467-476, 2010.

11. Terao Y, Nishida J, Horiuchi S, Rong F, Ueoka Y, Matsuda T, Kato H, Furugen Y, Yoshida K, Kato K and Wake N: Sodium butyrate induces growth arrest and senescence-like phenotypes in gynecologic cancer cells. Int J Cancer 94: 257-267, 2001.

12. Jüttermann R, Li E and Jaenisch R: Toxicity of 5-aza-2'-deoxycytidine to mammalian cells is mediated primarily by covalent trapping of DNA methyltransferase rather than DNA demethylation. Proc Natl Acad Sci USA 91: 11797-11801, 1994.

13. Zorn CS, Wojno KJ, McCabe MT, Kuefer R, Gschwend JE and Day ML: 5-Aza-2'-deoxycytidine delays androgen-independent disease and improves survival in the transgenic adenocarcinoma of the mouse prostate mouse model of prostate cancer. Clin Cancer Res 13: 2136-2143, 2007

14. McCabe MT, Low JA, Daignault S, Imperiale MJ, Wojno KJ and Day ML: Inhibition of DNA methyltransferase activity prevents tumorigenesis in a mouse model of prostate cancer. Cancer Res 66: 385-392, 2006.

15. Gravina GL, Marampon F, Di Staso M, Bonfili P, Vitturini A, Jannini EA, Pestell RG, Tombolini $\mathrm{V}$ and Festuccia C: 5-Azacitidine restores and amplifies the bicalutamide response on preclinical models of androgen receptor expressing or deficient prostate tumors. Prostate 70: 1166-1178, 2010.

16. Wu HC, Hsieh JT, Gleave ME, Brown NM, Pathak S and Chung LW: Derivation of androgen independent human LNCaP prostatic cancer cell sublines: role of bone stromal cells. Int J Cancer 57: 406-412, 1994.
17. Carmichael J, DeGraff WG, Gazdar AF, Minna JD and Mitchell JB: Evaluation of a tetrazolium-based semiautomated colorimetric assay: assessment of chemosensitivity testing. Cancer Res 47: 936-942, 1987.

18. Malikova J, Swaczynova J, Kolar Z and Strnad Z: Anticancer and antiproliferative activity of natural brassinosteroids. Phytochemistry 69: 418-426, 2008.

19. Tilley WD, Marcelli M and McPhaul MJ: Expression of the human androgen receptor gene utilizes a common promoter in diverse human tissues and cell lines. J Biol Chem 265: 13776-13781, 1990.

20. Trtkova K, Paskova L, Matijescukova N, Strnad M and Kolar Z: Binding of AR to SMRT/N-CoR complex and its co-operation with PSA promoter in prostate cancer cells treated with natural histone deacetylase inhibitor NaB. Neoplasma 57: 406-414, 2010.

21. Jarrard DF, Kinoshita H, Shi Y, Sandefur C, Hoff D, Meisner LF, Chang C, Herman JG, Isaacs WB and Nassif N: Methylation of the androgen receptor promoter $\mathrm{CpG}$ island is associated with loss of androgen receptor expression in prostate cancer cells. Cancer Res 58: 5310-5314, 1998.

22. Nakayama T, Watanabe M, Suzuki H, Toyota M, Sekita N, Hirokawa Y, Mizokami A, Ito H, Yatani R and Shiraishi T: Epigenetic regulation of androgen receptor gene expression in human prostate cancers. Lab Invest 80: 1789-1796, 2000.

23. Kinoshita H, Shi Y, Sandefur C, Meisner LF, Chang C, Choon A, Reznikoff CR, Bova GS, Friedl A and Jarrard DF: Methylation of the androgen receptor minimal promoter silences transcription in human prostate cancer. Cancer Res 60: 3623-3630, 2000.

24. Mancini DN, Singh SM, Archer TK and Rodenhiser DI: Sitespecific DNA methylation in the neurofibromatosis (NF1) promoter interferes with binding of CREB and SP1 transcription factors. Oncogene 18: 4108-4119, 1999.

25. Mishra DK, Chen Z, Wu Y, Sarkissyan M, Koeffler HP and Vadgama JV: Global methylation pattern of genes in androgensensitive and androgen-independent prostate cancer cells. Mol Cancer Ther 9: 33-45, 2010.

26. Cameron EE, Bachman KE, Myöhänen S, Herman JG and Baylin SB: Synergy of demethylation and histone deacetylase inhibition in the re-expression of genes silenced in cancer. Nat Genet 21: 103-107, 1999.

27. Dobosy JR and Selker EU: Emerging connections between DNA methylation and histone acetylation. Cell Mol Life Sci 58: 721-727, 2001.

28. Ahmed H: Promoter methylation in prostate cancer and its application for the early detection of prostate cancer using serum and urine samples. Biomark Cancer 2: 17-33, 2010.

29. Emanuele S, Lauricella M and Tesoriere G: Histone deacetylase inhibitors: apoptotic effects and clinical implications (Review). Int J Oncol 33: 637-646, 2008.

30. Marks PA and Xu WS: Histone deacetylase inhibitors: potential in cancer therapy. J Cell Biochem 107: 600-608, 2009.

31. Zhu WG and Otterson GA: The interaction of histone deacetylase inhibitors and DNA methyltransferase inhibitors in the treatment of human cancer cells (Review). Curr Med Chem Anticancer Agents 3: 187-199, 2003.

32. VanOosten RL, Earel JK Jr and Griffith TS: Histone deacetylase inhibitors enhance Ad5-TRAIL killing of TRAIL-resistant prostate tumor cells through increased caspase-2 activity. Apoptosis 12: 561-571, 2007.

33. Qiu J, Gao Z and Shima H: Growth of human prostate cancer cells is significantly suppressed in vitro with sodium butyrate through apoptosis. Oncol Rep 27: 160-167, 2012.

34. Walton TJ, Li G, Seth R, McArdle SE, Bishop MC and Rees RC: DNA demethylation and histone deacetylation inhibition co-operate to re-express estrogen receptor beta and induce apoptosis in prostate cancer cell-lines. Prostate 68: 210-222, 2008.

35. Tilley WD, Bentel JM, Aspinall JO, Hall RE and Horsfall DJ: Evidence for a novel mechanism of androgen resistance in the human prostate cancer cell line, PC-3. Steroids 60: 180-186, 1995.

36. Mizokami A and Chang C: Induction of translation by the 5'-untranslated region of human androgen receptor mRNA. J Biol Chem 269: 25655-25659, 1994. 